\title{
Isolation and Characterization of a Moderately Thermophilic Anaerobic Alkaliphile, Clostridium paradoxum sp. nov.
}

\author{
YOUHONG LI, ${ }^{1}$ LINDA MANDELCO, ${ }^{2}$ AND JUERGEN WIEGEL ${ }^{1 *}$ \\ Department of Microbiology and Center for Biological Resources Recovery, University of Georgia, \\ Athens, Georgia 30602-2605, 1 and Department of Microbiology, University of Illinois
} at Urbana-Champaign, Urbana, Illinois $61801^{2}$

\begin{abstract}
Alkaliphilic, moderately thermophilic anaerobic bacteria able to grow above pH 10.5 and $55^{\circ} \mathrm{C}$ were isolated from various sewage plants in the United States. The strains were motile with two to six peritrichous flagella and formed round to slightly oval terminal spores in terminally distended and slightly enlarged cells. Sporulated cells remained motile. The pH range for growth was between 7.0 and 11.1, with an optimum of around 10.1. At pH 10.1 the temperature range for growth was between 30 and $63^{\circ} \mathrm{C}$, with an optimum of $56^{\circ} \mathrm{C}$. The shortest observed doubling time (glucose) was around $16 \mathrm{~min}$ at $56^{\circ} \mathrm{C}$ and $\mathrm{pH} 10.1$. No dissimilatory sulfate reduction was detected. The organism utilized glucose, fructose, sucrose, maltose, and pyruvate but required yeast extract or tryptone for growth. Optimal $\mathrm{NaCl}$ concentrations for growth were between 50 and $200 \mathrm{mM}$. The guanine-plus-cytosine content was $30.0 \pm 0.10$ mol\%. On the basis of unique properties and 16S rRNA analysis, the strains are placed in a new species, Clostridium paradoxum, referring to the unusual retainment of motility by sporulated cells. Strain JW-YL-7 (DSM 7308) is designated as the type strain.
\end{abstract}

In recent years, alkaliphiles have attracted considerable attention in both fundamental and applied research $(10,11$, 26). One of the most stringent definitions for alkaliphiles is given by Krulwich and Guffanti (16), requiring an organism to have an optimum $\mathrm{pH}$ for growth $\left(\mathrm{pH}_{\mathrm{opt}}\right)$ of 10.0 and above to be counted as an alkaliphile. Whereas facultative alkaliphiles can grow in the neutral $\mathrm{pH}$ range, the obligate alkaliphiles cannot grow below $\mathrm{pH}$ 8.5. Alkaliphilic bacteria have been isolated from a variety of environments, representing a broad spectrum of taxonomic groups, with the most extensively studied being aerobic mesophilic strains belonging to the genus Bacillus $(11,15,16)$. Khraptsova (14) reported alkalitolerant thermophilic aerobes with an optimum growth temperature $\left(\mathrm{T}_{\mathrm{opt}}\right)$ of around $50^{\circ} \mathrm{C}\left(\mathrm{pH}_{\mathrm{opt}}, 8.0\right)$. According to Horikoshi (11), the highest reported growth temperature for an alkaliphilic aerobe, Bacillus sp. strain 221 (ATCC 2152), an alkaline protease producer, is $57^{\circ} \mathrm{C}$. However, little is known about alkaliphilic anaerobes, and even less is known about alkaliphilic thermophilic anaerobes. Among the archaea, one thermophilic (Methanobacterium thermoalcaliphilum: maximum growth temperature $\left[\mathrm{T}_{\max }\right]$, $<73^{\circ} \mathrm{C}$; $\mathrm{T}_{\text {opt }}, 58$ to $62^{\circ} \mathrm{C} ; \mathrm{pH}_{\text {opt }}, 7.5$ to 8.5 ; maximum $\mathrm{pH}$ for growth $\left.\left[\mathrm{pH}_{\text {max }}\right],<10\right)(5)$, one thermotolerant (Methanohalophilus zhilinae: $\mathrm{T}_{\max }, 55^{\circ} \mathrm{C}, \mathrm{T}_{\mathrm{opt}}, 45^{\circ} \mathrm{C} ; \mathrm{pH}_{\max },<10.5$; $\left.\mathrm{pH}_{\mathrm{opt}}, 9.2\right)(6)$, and several mesophilic methanogens, capable of growth at $\mathrm{pH}$ values above $\mathrm{pH} 9.5$, were isolated during the last decade $(18,21,38)$. In 1974, Souza et al. (28), reported the isolation of a mesophilic sporeforming anaerobe that grew between $\mathrm{pH} 8.0$ and 11.3 , but no subsequent characterization or other studies of the organism were reported. Recently, Shiba et al. (27) reported the isolation of four mesophilic strains of strictly anaerobic alkalitolerant halophiles which grew between $\mathrm{pH} 6.5$ and 10.0, and $\mathrm{Ni}$ imura et al. (23) described a facultative anaerobe, Amphibacillus xylanus, which grows between $\mathrm{pH} 8.0$ and 10.0 . To our knowledge, there has been no other report on the isolation and characterization of alkaliphilic anaerobic (eu)bacteria since the report of Souza et al. (28).

\footnotetext{
* Corresponding author.
}

In this report, we describe the isolation and characterization of an alkaliphilic thermophilic anaerobe capable of growth at $\mathrm{pH} 11.0$ and at temperatures above $60^{\circ} \mathrm{C}$. We propose to place the described strains in the new species Clostridium paradoxum $\mathrm{sp}$. nov.

\section{MATERIALS AND METHODS}

Isolation and culture conditions. One to two milliliters of liquid and 5 to $10 \mathrm{~g}$ of solid anaerobic and aerobic samples from anaerobic waste digestors and aeration pools (Table 1) were inoculated into $9 \mathrm{ml}$ of prereduced medium in Hungate tubes (borosilicate glass, 16 by $125 \mathrm{~mm}$; Bellco Glass, Inc., Vineland, N.J.) or $50 \mathrm{ml}$ of prereduced medium in $150-\mathrm{ml}$ serum bottles (Wheaton 400 borosilicate glass; Fisher Scientific Co., Pittsburgh, Pa.), respectively. The enrichment cultures were incubated at 50 to $60^{\circ} \mathrm{C}$ (higher temperatures lead to rapid deterioration of the complex growth medium). The medium was prepared by the Hungate technique (19), using an oxygen-free nitrogen atmosphere. The yeast extract-tryptone (YT) medium contained per liter $994 \mathrm{ml}$ of mineral base (consisting of $50 \mathrm{mM} \mathrm{Na}_{2} \mathrm{CO}_{3}, 2 \mathrm{mM} \mathrm{Na}_{2} \mathrm{HPO}_{4}$, and $1 \mathrm{mM} \mathrm{KCl}), 5 \mathrm{ml}$ of trace element solution (9), $1 \mathrm{ml}$ of vitamin solution (modified Wolfe solution [9]), $0.125 \mathrm{~g}$ of $\mathrm{Na}_{2} \mathrm{~S}, 0.125 \mathrm{~g}$ of cysteic acid, $1 \mathrm{mg}$ of resazurin (as a redox indicator), $5 \mathrm{~g}$ (or as indicated) of yeast extract, and $10 \mathrm{~g}$ (or as indicated) of tryptone. For the glucose-amended medium (YTG medium), prereduced sterile glucose was added separately to a final concentration of $0.3 \%$ (wt/vol) or as indicated. After the media were autoclaved, the $\mathrm{pH}$ was adjusted to 10.5 or as indicated using anaerobic sterile $2 \mathrm{~N}$ sodium hydroxide or potassium hydroxide. The amounts of yeast extract and tryptone were varied for specific purposes. The YTG medium for the enumeration contained the abovementioned mineral base supplemented with $0.5 \%$ yeast extract, $1 \%$ tryptone, and $0.3 \%$ glucose, $\mathrm{pH} 10.1$ to 10.3 (around the $\mathrm{pH}_{\mathrm{opt}}$ for this organism). If not stated differently, the purified cultures were routinely grown in the same YTG medium at $\mathrm{pH} 10.1$ to 10.5 . The $\mathrm{pH}$ of the media was measured with an Accument pH Meter (model 825 MP; Fisher Scientific) equipped with a combination $\mathrm{pH}$ electrode 
TABLE 1. Enumeration of $C$. paradoxum and other alkaliphilic anaerobic thermophiles

\begin{tabular}{|c|c|c|}
\hline Location, temperature, and $\mathrm{pH}$ of samples collected & $\begin{array}{l}\text { Alkaliphilic bacteria/ } \\
\text { ml of sample }{ }^{a}\end{array}$ & C. paradoxum-like strains isolated \\
\hline Anaerobic digestor, Athens, Ga.; $38^{\circ} \mathrm{C}, \mathrm{pH} 7.8$ & $500-1,000$ & JW/YL-A1, JW/YL-A3, JW/YL-A11 \\
\hline Aeration pool, Athens, Ga.; ambient, pH 6.9-7.5 & $500-1,000$ & $\begin{array}{l}\text { JW-YL-1, JW-YL-2, JW-YL-4, JW-YL-7 }{ }^{\mathrm{T}} \text {, } \\
\text { JW-YL-8, JW-Yl-12 }\end{array}$ \\
\hline Anaerobic digestor, Atlanta, Ga.; $38-42^{\circ} \mathrm{C}$, pH 7.9 & $1,000-10,000$ & JW/YL-L1, JW/YL-L5 \\
\hline Aeration pool, Atlanta, Ga.; ambient, $\mathrm{pH} 7.4$ & $100-1,000$ & JW/YL-L15, JW/YL-L21 \\
\hline Anaerobic digestor, Beaverton, Oreg.; $37^{\circ} \mathrm{C}, \mathrm{pH}$ 6.4-7.0 & $100-1,000$ & JW/YL-01, JW/YL-05, JW/YL-09 \\
\hline Anaerobic digestor, Miami, Fla.; $25-30^{\circ} \mathrm{C}$, pH 7.1 & 100 & JW/YL-F1, JW/YL-F6, JW/YL-F10 \\
\hline Anaerobic digestor, Gulf Breeze, Fla.; ambient, $\mathrm{pH} 7.5-7.0$ & $50-100$ & JW/YL-F11, JW/YL-F12 \\
\hline Anaerobic digestor, Norman, Okla.; $35^{\circ} \mathrm{C}$, pH 7.0-7.4 & $100-500$ & JW/YL-Ok1, JW/YL-Ok2, JW/YL-OK5 \\
\hline Digester effluent, San Francisco, Calif.; ambient, pH 7.0 & $10-50$ & JW/YL-SF4, JW/YL-SF5 \\
\hline Anaerobic digestor, San Francisco, Calif.; $37^{\circ} \mathrm{C}, \mathrm{pH} 7.3$ & $100-1,000$ & JW/YL-SF6, JW/YL-SF7, JW/YL-SF8 \\
\hline
\end{tabular}

${ }^{a}$ The most probable number determination was done at $\mathrm{pH} 10.1$ and $60^{\circ} \mathrm{C}$ using YTG medium; additional strains were isolated growing at 55 but not at $60^{\circ} \mathrm{C}$.

(Sensor, Stanton, Calif.) and a temperature probe (catalog no. 13-620-16; Fisher Scientific) for temperature corrections. The isolation of pure cultures from liquid enrichment cultures $\left(50\right.$ to $\left.60^{\circ} \mathrm{C}\right)$ was done by repeated subculturing at $50^{\circ} \mathrm{C}$ and $\mathrm{pH} 10.8$, the highest $\mathrm{pH}$ still yielding moderately fast growth, followed by four or more rounds of isolation of single colonies in agar shake-roll tubes (19), using YTG or YTP medium ( $\mathrm{pH} 10.5$ to $11.0,50^{\circ} \mathrm{C}$ ) amended with $2 \%$ agar (Difco Laboratories, Detroit, Mich.). This included isolation of colonies from heat-treated $\left(5 \mathrm{~min}, 100^{\circ} \mathrm{C}\right)$ inocula containing sporulated cells. YTP medium contained $0.3 \%$ yeast extract, $0.3 \%$ tryptone, and $0.2 \%$ peptone plus the same mineral base. Growth was determined by measuring the increase in optical density at $600 \mathrm{~nm}\left(\mathrm{OD}_{600}\right)$ with a Spectronic 21 colorimeter (Bausch \& Lomb, Inc., Rochester, N.Y.).

To further ensure the purity of the type culture, strain JW-YL- $7^{\mathrm{T}}$ was repeatedly cultured (at $50^{\circ} \mathrm{C}$ ) in four separate lines, an alkaline line at $\mathrm{pH} 10.8$ to 11.0 and a neutral one at $\mathrm{pH} 7.4$ to 7.6, each with or without glucose; these established cultures were then subjected twice to separate serial dilutions (final dilutions, 1:1) into liquid medium. The highest dilutions grown up under each set of conditions were heat treated $\left(100^{\circ} \mathrm{C}\right.$ for $\left.2 \mathrm{~min}\right)$ and then inoculated into agarsolidified medium. Cultures incubated at $\mathrm{pH} 7.5$ (with or without glucose) were not subjected to heat treatment because of their failure to form heat-stable spores at neutral $\mathrm{pH}$ (see below). The four lines of cultures finally obtained (alkaline line with and without glucose and neutral line with and without glucose) were each grown under all four conditions and compared with respect to morphology, sporulation, and doubling times.

Light and electron microscopy. A phase-contrast microscope (Model PM-10AD; Olympus Optical Co., Ltd., Tokyo, Japan) was used for routine examination and for obtaining photomicrographs of the organism. Electron microscopy (negative staining and ultrathin section) was performed with a JEM-100 CXII Electron Microscope (JEOL, Tokyo, Japan). Negative staining of cells was done with $2 \%$ uranyl acetate according to Valentine et al. (30) and Beuscher et al. (3). The preparation of samples for ultrathin sectioning was done as described previously $(8,13,29)$, using uranyl acetate and lead citrate for poststaining. The Gram type was determined by using the unequivocal lipopolysaccharide-polymyxin B assay as described previously (35).

pH and temperature ranges. The $\mathrm{pH}$ range for growth was determined by growing the bacteria at $50^{\circ} \mathrm{C}$ in Hungate tubes. The YT medium (used in order to avoid interference through caramelization of sugars at the extreme $\mathrm{pH}$ values) was kept within $\pm 0.1 \mathrm{pH}$ unit of the initial $\mathrm{pH}$ by frequent adjustment with anaerobic sterile $2 \mathrm{~N} \mathrm{NaOH}$. Growth was determined by monitoring the increase of the $\mathrm{OD}_{600}$ against three incubated blank control tubes. Cultures were incubated for up to 10 days to determine no-growth boundaries. The temperature range for growth was determined in Hungate tubes containing $5 \mathrm{ml}$ of YT or YTG at pH 10.1 in a temperature gradient incubator (Scientific Industries, Inc., Bohemia, N.Y.) set from 20 to $71^{\circ} \mathrm{C}$ with a shaking speed of $15 \mathrm{rpm}$.

Substrate utilization. To a base medium $\left(50 \mathrm{mM} \mathrm{Na}_{2} \mathrm{CO}_{3}\right.$, $1 \mathrm{mM} \mathrm{KCl}, 2 \mathrm{mM} \mathrm{Na} \mathrm{HPO}_{4}, 0.1 \%$ [wt/vol] yeast extract, 5 $\mathrm{ml}$ of trace element solution per liter, $1 \mathrm{ml}$ of vitamin solution per liter, and reducing agents as described above [ $\mathrm{pH} 9.6])$, sterile anaerobic test substrates $(0.5 \%$ [wt/vol] final concentration) were added. The suboptimal $\mathrm{pH}$ was chosen to minimize possible alterations (Lobry deBruyn reaction) of various carbohydrates at the alkaline $\mathrm{pH}$ values. Tubes were inoculated with $2 \%(\mathrm{vol} / \mathrm{vol})$ of a culture exponentially growing at $50^{\circ} \mathrm{C}$. Increase in optical density and $\mathrm{pH}$ changes were monitored. Two controls (inoculated base medium containing $0.2 \%$ [wt/vol] yeast extract and no added carbon source) were set up for each test strain. Reported $\mathrm{OD}_{600}$ values were corrected for growth in these controls. Substrate utilization was assumed when an increase in $\mathrm{OD}_{600}$ of 0.1 or above was recorded. Assays were performed in duplicate. Cultures showing marginal growth $\left(\mathrm{OD}_{600}\right.$ between 0.07 and 0.14 ) were subcultured for confirmation of growth on this substrate; the maximal incubation time was 10 days.

Fermentation products. $\mathrm{H}_{2}, \mathrm{CO}_{2}$, and $\mathrm{CH}_{4}$ were determined on a gas chromatograph (Varian, Walnut Creek, Calif.) equipped with a Porapak Q (80/100 mesh) column (Supelco, Inc., Bellefonte, $\mathrm{Pa}$.), a flame ionization detector (for $\mathrm{CH}_{4}$ determinations), and a thermal conductivity detector (for $\mathrm{CO}_{2}$ and $\mathrm{H}_{2}$ determinations). Volatile fatty acids and alcohols, as well as nonvolatile fatty acids, were analyzed as described previously (34) by using a Hewlett-Packard 5880A Gas Chromatograph (Hewlett-Packard, Avondale, Pa.) equipped with a Chromosorb WAW 10\% sp-100 glass column (Supelco) and a flame ionization detector. Glucose and acetate were determined by enzymatic assays (catalog no. 139106 and 148261, respectively; Boehringer GmbH, Mannheim, Germany).

Dissimilatory sulfate reduction. The dissimilatory sulfate reduction test was performed with Hungate tubes containing medium which consisted of $0.3 \%$ (wt/vol) yeast extract, $0.5 \%(\mathrm{wt} / \mathrm{vol})$ tryptone, $0.3 \%(\mathrm{wt} / \mathrm{vol})$ glucose, $0.0025 \%$ 
TABLE 2. Evolutionary distances between $C$. paradoxum and selected members of the clostridial subphylum ${ }^{a}$

\begin{tabular}{|c|c|c|c|c|c|c|c|c|c|c|c|c|c|c|c|c|c|c|}
\hline \multirow{2}{*}{ Organism } & \multicolumn{18}{|c|}{ Evolutionary distance } \\
\hline & 1 & 2 & 3 & 4 & 5 & 6 & 7 & 8 & 9 & 10 & 11 & 12 & 13 & 14 & 15 & 16 & 17 & 18 \\
\hline \multicolumn{19}{|c|}{ 1. C. thermosaccharolyticum } \\
\hline 2. C. thermoaceticum & 13.0 & & & & & & & & & & & & & & & & & \\
\hline 3. C. pasteurianum & 18.7 & 17.6 & & & & & & & & & & & & & & & & \\
\hline 4. C. butyricum & 19.6 & 19.3 & 7.8 & & & & & & & & & & & & & & & \\
\hline 5. C. perfringens & 18.0 & 19.2 & 9.4 & 7.4 & & & & & & & & & & & & & & \\
\hline 6. C. oroticum & 21.5 & 19.3 & 17.8 & 17.2 & 16.2 & & & & & & & & & & & & & \\
\hline 7. C. aminovalericum & 21.0 & 19.0 & 18.0 & 17.8 & 17.0 & 8.1 & & & & & & & & & & & & \\
\hline 8. C. purinolyticum & 18.1 & 16.2 & 14.4 & 15.2 & 15.3 & 16.9 & 15.3 & & & & & & & & & & & \\
\hline 9. C. lituseburense & 20.6 & 18.2 & 17.9 & 16.8 & 15.2 & 15.9 & 15.2 & 13.5 & & & & & & & & & & \\
\hline 10. E. tenue & 19.8 & 17.4 & 16.8 & 17.4 & 14.4 & 15.2 & 15.6 & 13.0 & 3.8 & & & & & & & & & \\
\hline 11. C. sordellii & 20.0 & 17.4 & 16.7 & 17.1 & 14.6 & 14.7 & 14.9 & 12.9 & 3.7 & 1.2 & & & & & & & & \\
\hline 12. C. paradoxum & 17.5 & 15.4 & 17.1 & 18.1 & 15.2 & 17.1 & 17.7 & $\mathbf{1 3 . 3}$ & 9.5 & 7.7 & 7.9 & & & & & & & \\
\hline 13. C. mangenotii & 21.0 & 18.4 & 18.1 & 17.1 & 14.9 & 16.2 & 16.2 & 15.3 & 6.9 & 6.3 & 6.3 & 11.5 & & & & & & \\
\hline 14. C. sticklandii & 20.5 & 18.3 & 17.6 & 18.3 & 16.0 & 17.7 & 17.3 & 15.8 & 12.4 & 10.7 & 10.7 & 11.0 & 13.4 & & & & & \\
\hline 15. C. barkeri & 18.7 & 17.9 & 17.1 & 19.0 & 17.5 & 20.2 & 19.2 & 14.6 & 18.3 & 17.5 & 17.8 & 18.9 & 18.1 & 19.4 & & & & \\
\hline 16. C. quercicolum & 19.3 & 16.1 & 20.8 & 22.5 & 22.6 & 22.3 & 21.2 & 18.1 & 20.8 & 20.7 & 20.8 & 20.9 & 20.6 & 22.7 & 20.6 & & & \\
\hline 17. M. elsdenii & 19.7 & 17.2 & 22.1 & 23.4 & 23.9 & 22.3 & 21.9 & 20.1 & 22.5 & 23.3 & 23.0 & 23.0 & 25.1 & 22.3 & 23.4 & 12.9 & & \\
\hline 18. B. subtilis & 19.2 & 15.4 & 15.8 & 17.8 & 17.4 & 19.5 & 19.3 & 16.5 & 18.5 & 17.8 & 18.0 & 17.1 & 18.7 & 19.4 & 16.8 & 17.5 & 21.1 & \\
\hline
\end{tabular}

${ }^{a}$ Only those positions having a known base in all sequences in the set of organisms were used in the analysis. Approximately 1,290 positions were used in the analysis. C., Clostridium; B., Bacillus; E., Eubacterium; M., Megasphaera. B. subtilis served as an outgroup.

cysteine $\cdot \mathrm{HCl}, 0.1 \% \mathrm{Na}_{2} \mathrm{SO}_{4}$, and $0.01 \% \mathrm{FeSO}_{4}, \mathrm{pH} 10.1$. The cultures were incubated at $50^{\circ} \mathrm{C}$ for up to 5 days. Two uninoculated tubes were used as controls.

Susceptibility to antibiotics. Susceptibility to antibiotics was determined by transferring $(3 \%$, vol/vol) an exponentially growing culture into fresh YTG medium containing 5 to $100 \mu \mathrm{g}$ of filter-sterilized $\mathrm{O}_{2}$-free antibiotics per $\mathrm{ml}$ and incubating at $50^{\circ} \mathrm{C}$ and $\mathrm{pH} 7.4$ and 10.1 . Attempts to subculture the incubated cultures in medium without antibiotics were used to test for a bacteriostatic or bacteriocidal effect of the antibiotics.

Metal content of the medium and sewage sludge samples. The concentrations of $\mathrm{Na}^{+}, \mathrm{K}^{+}$, and other metal ions in the sediment samples from the Athens sewage plant as well as in the employed media were determined with a plasma emission spectroscope (Jarrell-Ash 965 ICP; Thermo Jarrell Ash Corporation, Franklin, Mass.).

Determination of mole percent $\mathbf{G}+\mathbf{C}$. DNA was isolated according to Ausubel et al. (2), using $\mathrm{CsCl}$ gradient ultracentrifugation. The guanine plus cytosine content (mole percent $\mathrm{G}+\mathrm{C}$ ) was determined after enzymatic digestion and highperformance liquid chromatography (HPLC) separation of the nucleosides as described by Whitman et al. (32) and Mesbah et al. (22).

Effect of $\mathrm{Na}^{+}$and $\mathrm{K}^{+}$on growth, motility, and sporulation. The effect of sodium ion on growth, motility, and sporulation was investigated by inoculating 3\% (vol/vol) of an exponentially growing culture into a YTG medium (pH 9.6 and $\mathrm{pH}$ 7.5 without $\mathrm{Na}$ carbonate but containing various amounts of $\mathrm{NaCl}, \mathrm{KCl}, \mathrm{NaOH}$, or $\mathrm{KOH}$ and $0.25 \%$ yeast extract, $0.25 \%$ tryptone, and $0.3 \%$ glucose).

$16 S$ rRNA isolation, sequencing method, and data analysis. The 16S rRNA was isolated from the two strains JW-YL-7 and JW/YL-L15 by customary procedures $(20,37)$. The dideoxynucleotide chain termination method $(4,25)$ adapted for direct rRNA sequencing using reverse transcriptase (17) was employed. Synthesized strands were labeled by the inclusion of $\left[\alpha-{ }^{35}\right.$ S $]$ thio-dATP (4). A standard set of primers (usually eight) specific for (eu)bacterial 16S rRNAs (4, 17, 31 ) was routinely used. All sequences were $>90 \%$ complete. The sequences were aligned in the sequence editor ae2
(C. R. Woese, University of Illinois) against a representative collection of (eu)bacterial 16S rRNAs $(24,36)$. Corrected pairwise distances (expressed as estimated changes per 100 nucleotides) were computed from percent similarities by using the Jukes and Cantor correction (12) as modified by G. J. Olsen (described in reference 31 ) to accommodate the actual nucleotide ratios. Dendograms were constructed from evolutionary distance matrices by using the algorithm of De Soete (7).

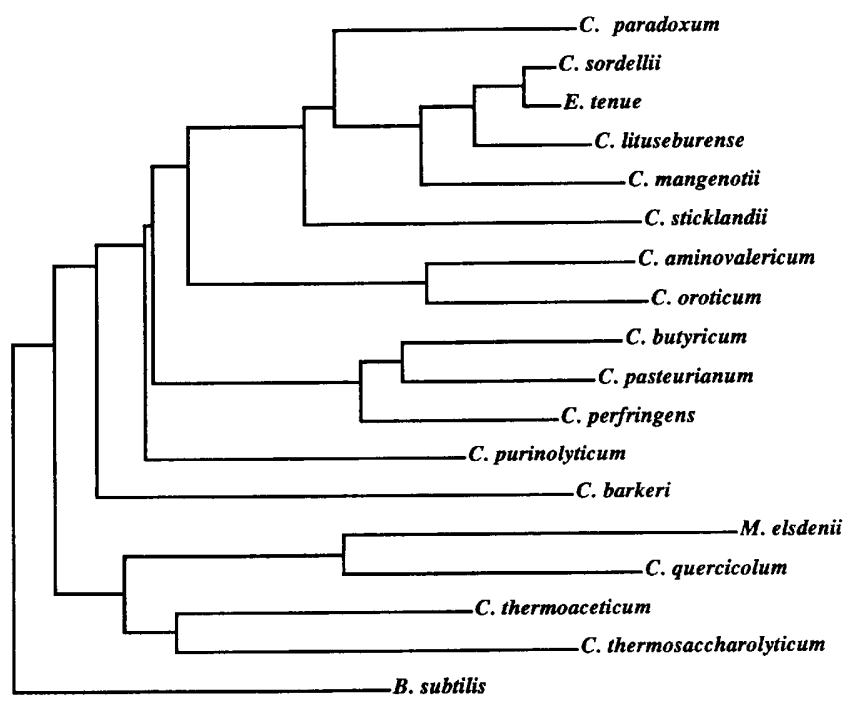

$10 \%$

FIG. 1. Phylogenetic tree for C. paradoxum and related organisms based on 16S rRNA sequences (see Materials and Methods and Table 2). The bar represents 10 inferred changes per 100 nucleotides. C., Clostridium; B., Bacillus; M., Megasphaera. Bacillus subtilis has been used to root the tree. 

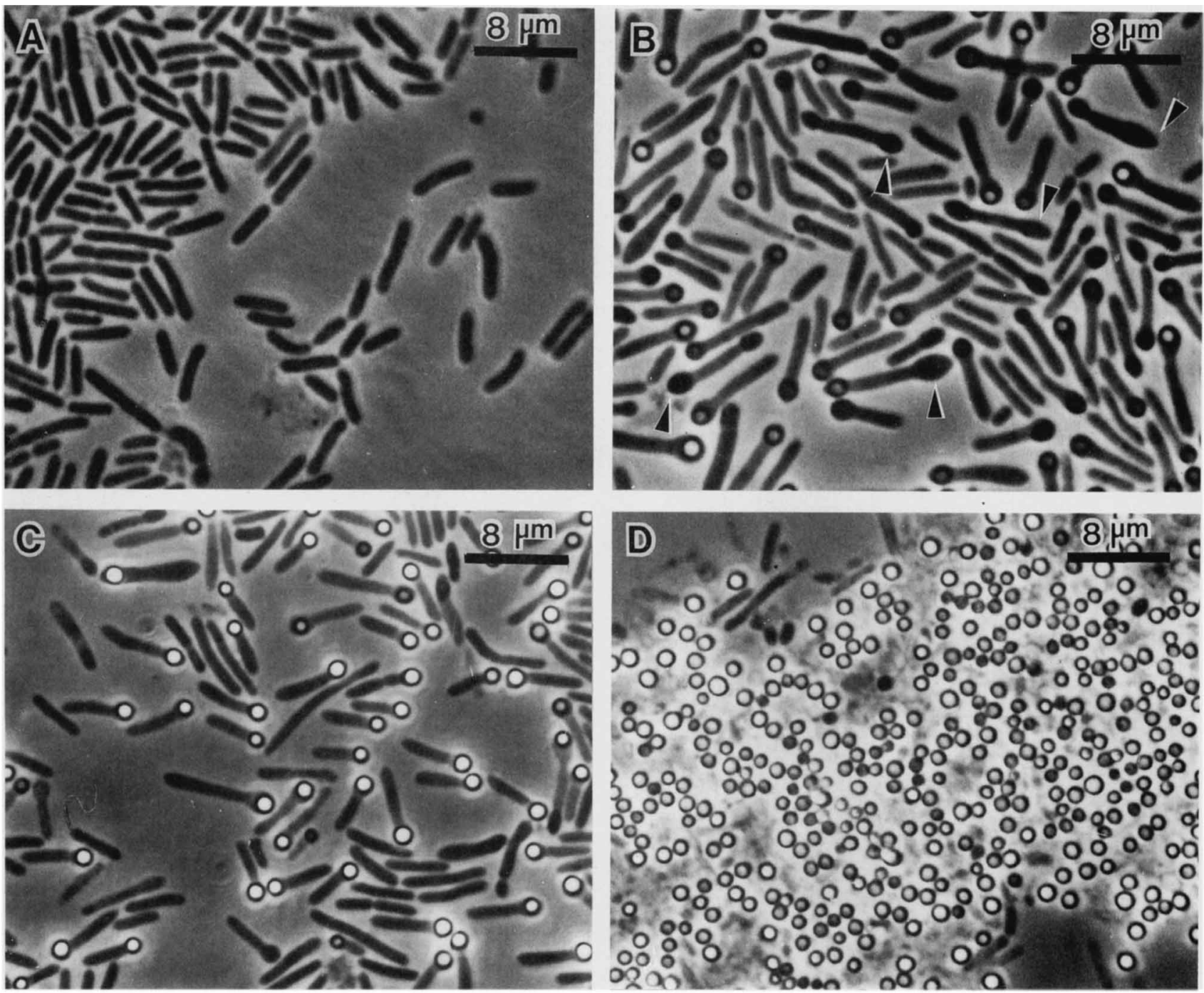

FIG. 2. Light micrographs of C. paradoxum in early (A) and late (B) exponential, stationary (C), and death or free-spore (D) phases.

Nucleotide sequence accession number. The GenBank accession number for the $16 \mathrm{~S}$ rRNA sequence of the type strain is L06838.

\section{RESULTS AND DISCUSSION}

Enumeration of alkaliphilic thermophilic anaerobes. At $\mathrm{pH}$ 10.2 and $60^{\circ} \mathrm{C}$, most probable number counts (Table 1 ) of alkaliphilic thermophilic anaerobes in sewage sludge samples taken from various sewage plants (anaerobic digestors and aeration pools) in the United States ranged from about 50 to 10,000 bacteria per $\mathrm{ml}$ of wet sample ( 3 to $7 \%$ solid content). The tested effluent samples (sewage plants in San Francisco, Calif., and Athens, Ga.; see discussions below), had significantly lower counts than the corresponding anaerobic digestor samples. At the Athens, Ga., site, two samples of water and sediment were taken from the discharge channel of the sewage plant; two further sediment samples were taken from the bank of the Oconee River at 0.1 and 2 to $3 \mathrm{~km}$ downstream from the sewage plant. Furthermore, samples were taken $0.2 \mathrm{~km}$ upstream from the plant. The enrichment and enumeration (most probable number) of these samples, however, failed to yield any organism similar to the organism isolated from the aeration pools and anaerobic digesters. Although others $(10,11,15$, and 16 and authors cited therein) and, recently, we have isolated many (over 150) alkalitolerant strains from various samples, including from hot springs, forest soils, agricultural soils, saline lakes, and sediments from rivers and freshwater lakes (unpublished data), no facultative or obligate alkaliphiles (using the definition of Krulwich and Guffanti [16]) were obtained from these samples.

Isolation of alkaliphilic thermophilic strains. About 29 strains of anaerobic bacteria, able to grow above $\mathrm{pH} 10.5$ at $60^{\circ} \mathrm{C}$, were isolated as described in Materials and Methods from samples obtained from sewage plants in the United States (Table 1). The isolates proved to be quite similar to one another, especially the strains from Athens and San Francisco, which were very much alike in morphology, sporulation, and motility of sporulated cells. Similar strains were isolated from the anaerobic digestor sludge of the plant in Athens and from the aeration pool, which periodically received return sludge from the clarifier and anaerobic 

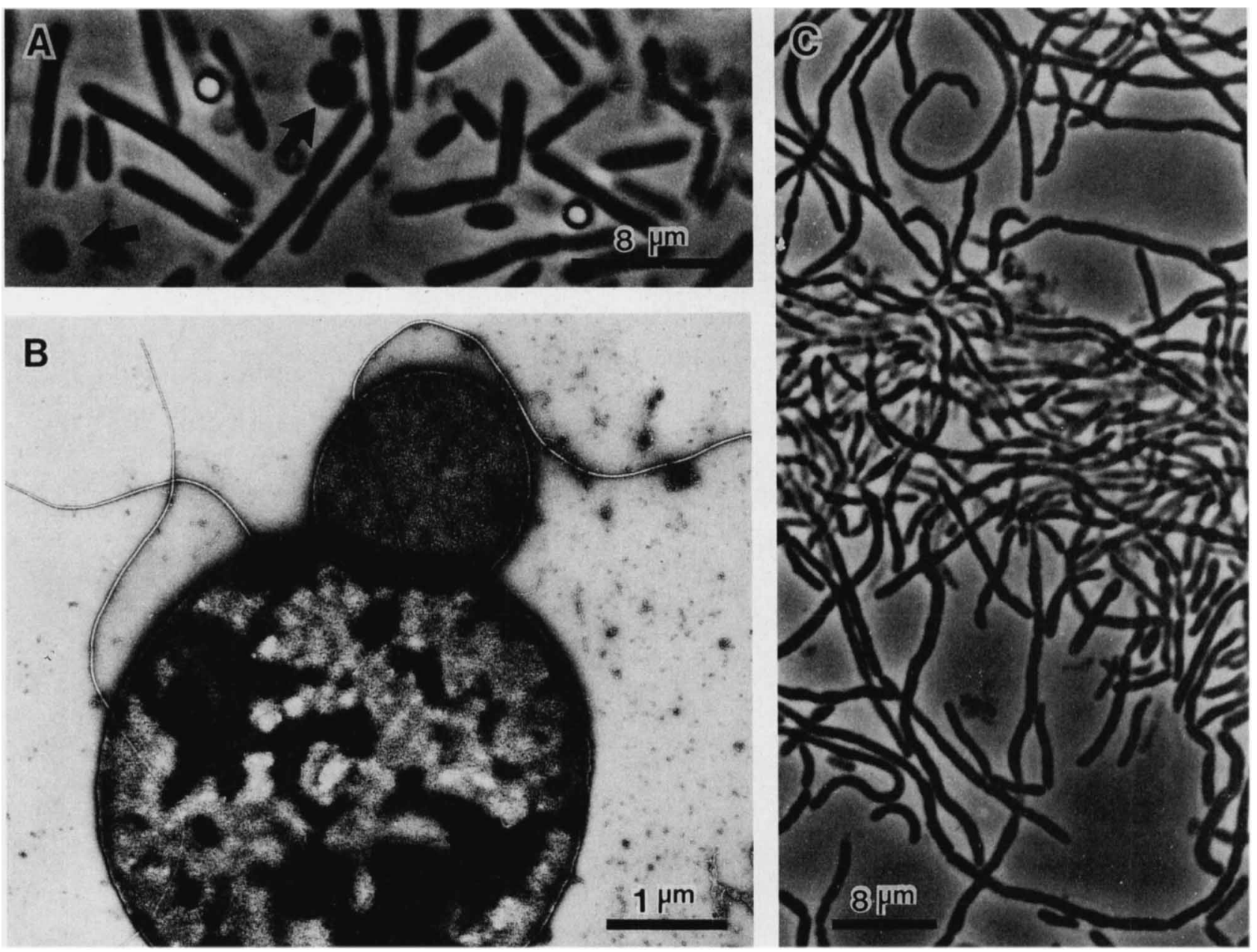

FIG. 3. Light (A) and electron (B) micrographs of $C$. paradoxum L-form cells. The arrow indicates an L-form cell within the phase-contrast microphotograph. (C) Light microscopy (phase contrast) of filamentous cells grown at extreme alkaline $\mathrm{pH}$ (10.9 to 11.1).

digestor. To our knowledge, this is the first isolation of truly alkaliphilic anaerobic thermophilic bacteria.

Because of the observed morphological variability and the biphasic pH curves (see below) strain JW-YL- $7^{\mathrm{T}}$ was established in four different culture lines (representing four different growth conditions as described in Materials and Methods) to verify the uniformity of this strain. Consequently, each line was grown at $50^{\circ} \mathrm{C}$ under those four sets of conditions, i.e., in the presence and absence of glucose at pH 10.8 to 11.0 (alkaline lines) and 7.4 to 7.6 (neutral lines). A comparison of properties (including morphology, motility, extent of sporulation, and doubling times) revealed no differences among the four lines when subcultured under the same conditions. We concluded that the culture JW-YL- $7^{\mathrm{T}}$ is an axenic strain. The biphasic $\mathrm{pH}$ curve was observed with all the strains tested (JW-YL-1, JW-YL-2, JW-YL-4, JWYL-8, JW-YL-12, and JW/YL-L15). Thus, on the basis of these results and the extended tests done with the type strain, JW-YL-7, we conclude that the biphasic $\mathrm{pH}$ curve is a general feature for $C$. paradoxum and that, with respect to the other tested strains, the biphasic $\mathrm{pH}$ dependency curves do not indicate that the cultures were impure.

$16 S$ rRNA analysis. The $16 \mathrm{~S}$ rRNA sequence analysis of strains JW-YL- $7^{\mathrm{T}}$ and JW/YL-L15 placed them into the Clostridium-Bacillus subphylum (Table 2; Fig. 1). The two strains were indistinguishable at the 16S rRNA level. Clostridium sordellii and Eubacterium tenue are the closest related species (Table 2; Fig. 1). Thus, the two strains are clearly separated from the cluster of species around the type species Clostridium butyricum, which are regarded as clostridia sensu stricto. The new strains are also separated from the other two anaerobic thermophiles for which sequence analyses were available, Clostridium thermoaceticum and Clostridium thermosaccharolyticum. Consequently, on the basis of the results of the $16 \mathrm{~S}$ rRNA analysis, the unique $\mathrm{pH}$ and temperature range for growth, and the motility of sporulated cells, we concluded that the isolated strains do not belong to a validly published species. Thus, the strains were placed tentatively into a new clostridial species until the genus Clostridium is redefined, the relationship to other thermophiles has been elucidated on the 16S rRNA level, and an International Committee of Systematic Bacteriology subcommittee has established rules for reclassification of the presently described Clostridium species.

Description of Clostridium paradoxum sp. nov. The following characterization of the new clostridial species is based on the properties of the type strain, JW-YL-7. Physiological and morphological properties were corroborated with the strains JW-YL-1, JW-YL-2, JW-YL-4, JW-YL-8, JW-YL-12, and JW/YL-L15, isolated from the sewage plant in Athens and 

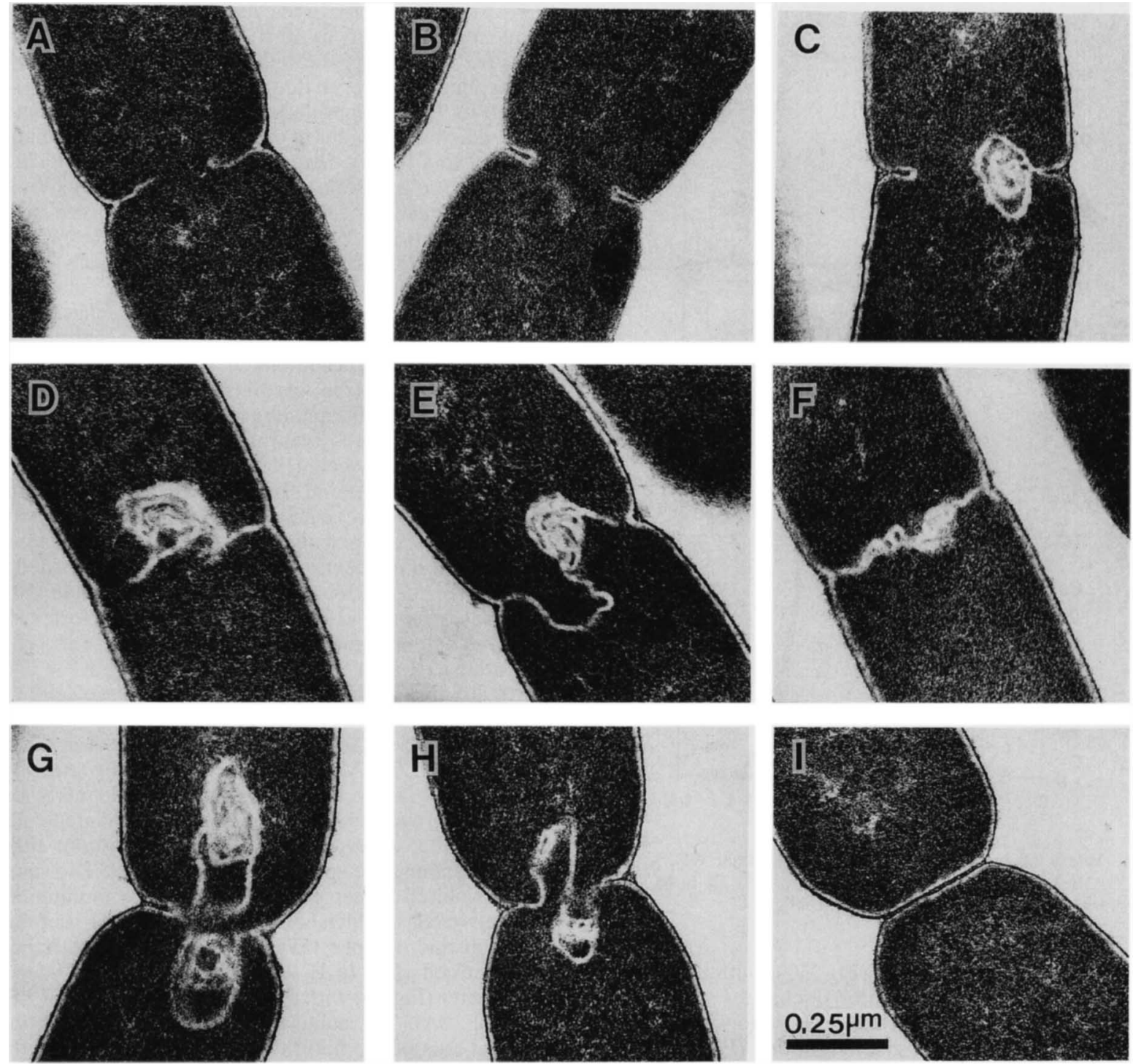

FIG. 4. Electron micrographs of ultrathin sections of dividing cells. (A to F) Early stage; (G to $\mathrm{H}$ ) later stage; (I) completion of division. Note the frequently observed formation of excess membranes at the site of cell division.

Atlanta, Ga. (Table 1). On the basis of the ability to grow at the high $\mathrm{pH}$ values of 10.5 and above, the morphology of the vegetative and sporulated cells, and the motility of the sporulated cells, the additional strains listed in Table 1 are assumed to belong to the same species. However, no numerical taxonomy has been done to further verify this assumption.

Clostridium paradoxum sp. nov.; para.doxum. Gr. para (akin to Gr. pro, before, ahead) plus doxos (fr. Gr. dokein, to seem, to think, opinion); Gr. paradoxon, fr. neut. of paradoxos, contrary to expectation; M.L. paradoxum, referring to the unusual property of sporulated cells to be highly motile.

Colony morphology. In agar shake-roll tubes containing YTP medium without glucose at $\mathrm{pH} 10.0$ to 10.5 and $50^{\circ} \mathrm{C}$, the agar surface colonies were white, translucent, and circular to slightly irregular. Colonies in the agar were lens shaped and creamy white. No pigmentation was observed when cells were grown in either liquid or on solidified YTP and YTG media. After 3 to 5 days, colonies usually started to turn transparent as the cells began to form autoplasts ( $\mathrm{L}$ form) and to lyse.

Morphology of vegetative cells. Exponential cells, grown in liquid or agar-solidified medium, were rods of 0.7 to $1.1 \mu \mathrm{m}$ in diameter and 2 to $4.5 \mu \mathrm{m}$ in length. Chains of two and more cells were seen in the early exponential phase. When grown at the optimal $\mathrm{pH}$ of 10.1 and at $50^{\circ} \mathrm{C}$, the cells from the exponential growth phase were regular to slightly bent rods (Fig. 2A). The morphology became more pleiomorphic in the stationary growth phase (within 6 to $20 \mathrm{~h}$ ), with slightly deformed, swollen or curved cells (Fig. 2B and C). Occasionally, L-form types of cells were seen, mainly during prolonged incubation ( 1 to 2 days or longer) at either elevated temperatures $\left(55\right.$ to $60^{\circ} \mathrm{C}$ ) or low pH values (around

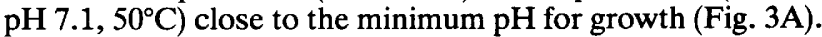
Some of these cells still possessed flagella (Fig. 3B) and stayed motile. At or near the $\mathrm{pH}_{\max }(10.9$ to 11.1$)$ at $50^{\circ} \mathrm{C}$ or around 60 to $63^{\circ} \mathrm{C}$ at $\mathrm{pH} 10.1$, the organism frequently 


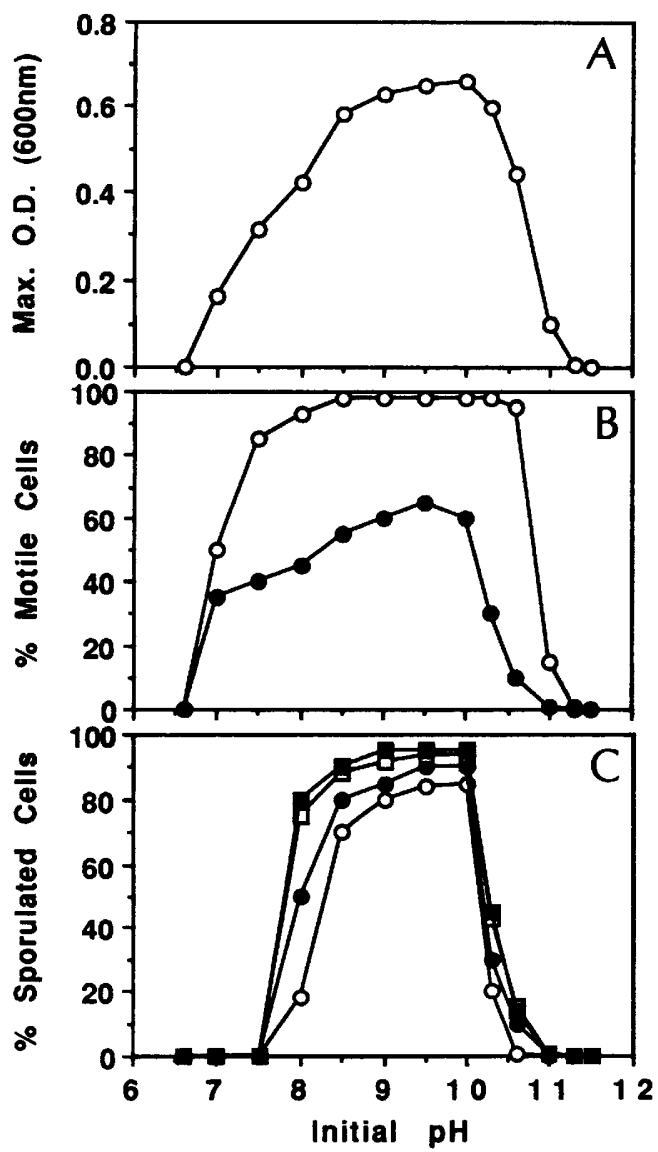

FIG. 5. Effect of initial $\mathrm{pH}$ on growth (maximal $\mathrm{OD}_{600}$ ) (A), motility (B), and sporulation (C). $0,3 \mathrm{~h} ; 0,6 \mathrm{~h} ; \square, 25 \mathrm{~h} ; \mathbf{0}, 72 \mathrm{~h}$. YTG medium was used; incubation was at $50^{\circ} \mathrm{C}$.

developed into filamentous rods (Fig. 3C), with a length of up to $50 \mu \mathrm{m}$, without visual septation or changes in diameter. The electron micrographs revealed a variation in cell division. Some stages suggest a pinching mode (Fig. 4A to $\mathrm{C}$ ) while others indicate more of a septation mechanism (Fig. $4 \mathrm{D}$ to $\mathrm{H}$ ). Frequently, dividing cells showed the formation of excess membrane structures (Fig. $4 \mathrm{C}$ to $\mathrm{H}$ ), indicating that the cell division process might be inhibited. On the other hand, at this time, it cannot be excluded that this is an artifact caused by the fixation process for electron microscopy.

Gram stain reaction and Gram type. The Gram stain reaction was negative, regardless of the growth phase; however, the test for the formation of the lipopolysaccharide-polymyxin B complex gave no indication of the presence of lipopolysaccharide (35). Thus, the organism is regarded as a Gram-type-positive organism (31). This is also indicated by the fine structure of the cell wall, although atypically thin for a Gram-type-positive bacterium, as revealed in the photomicrographs of ultrathin sections (Fig. 4). This is also in agreement with the data from the 16S rRNA sequence analysis, indicating that the organism belongs to the Gram-type-positive Clostridium and Bacillus subphylum (Fig. 1).

Sporulation. Generally, high rates of sporulation (up to 90\%) were observed in both liquid and solidified agar YTG media, leading to the formation of swollen sporangia of the "drumstick" type (Fig. 2B and C). Spores were round and 1 to $1.1 \mu \mathrm{m}$ in diameter. In the absence of glucose, sporulation frequency decreased to 10 to $20 \%$. During growth on glucose, the majority of the cells sporulated after 24 to $48 \mathrm{~h}$ of incubation. The sporulation was $\mathrm{pH}$ dependent (Fig. 5). At $\mathrm{pH} 7.0$ to 7.5 , no sporulation was seen with the vegetative cells, which were wider in diameter $(1$ to $1.1 \mu \mathrm{m})$ than at $\mathrm{pH}$ $10.1(0.7$ to $1.0 \mu \mathrm{m})$. During growth at $\mathrm{pH} 10.9$ to 11.0 , the vegetative cells developed into a pseudofilamentous form and the frequency of sporulation decreased from 85 to $95 \%$ (at $\mathrm{pH} \mathrm{10.1)} \mathrm{to} 1$ to $5 \%$. The formation of spores was usually observed during the late exponential or early stationary phase; the ratio of spores and vegetative cells remained relatively constant during the stationary phase until the inception of death phase, when the cells began to lyse and the released spores accumulated into large clumps (Fig. 2D). The clumps of spores were seen in both shaken and unshaken cultures. Frequently, the formation of structures resembling prespores was seen on the distal end of the sporulated mother cell (Fig. $2 B$ and $C$ ), with no visible septation (Fig. 6A and B). The electron micrograph of ultrathin sections revealed the typical endospore structure for the fully developed spore (Fig. 6C). Sporulation was also dependent on concentrations of $\mathrm{Na}^{+}$and $\mathrm{K}^{+}$added to the medium (Fig. 7), exhibiting a very sharp optimum (50 to 150 $\mathrm{mM} \mathrm{NaCl}$ ) in the absence of added $\mathrm{KCl}$. No sporulation occurred below $10 \mathrm{mM} \mathrm{NaCl}$ regardless of whether 25 or 100 $\mathrm{mM}$ added $\mathrm{KCl}$ was present.

Motility and flagellation. The motility of the cells was $\mathrm{pH}$ dependent (Fig. 5) and was also influenced by the concentrations of sodium and potassium ions present in the culture medium (Fig. 7). At pH 10.1, exponentially growing cells were motile, as were most of the cells in early or midstationary growth phase. Surprisingly, sporulated cells were highly motile, with swimming in the direction of either end (i.e., containing the spore or not) of the cell. The sporulated cells exhibited longer phases of smooth swimming than the vegetative cells, which appeared to tumble most of the time. Electron micrographs revealed two to six peritrichous flagella per cell of up to 12 to $15 \mu \mathrm{m}$ in length and 90 to $92 \mathrm{~nm}$ in diameter (Fig. 8), with a flagellum wave length of 2.0 to 2.2 $\mu \mathrm{m}$ (Fig. 8A). The subunits are helically packed along the filament axis of the flagellum with an angle of less than $60^{\circ}$ formed between the axis of the longitudinal rows of subunits and the axis tangential to the left or right oblique rows of subunits (Fig. 8B), representing the type II flagellum as defined by Aragno et al. (1).

Growth properties. (i) Effects of $\mathrm{pH}$ and temperature on growth. The $\mathrm{pH}$ range for growth was 7.3 to 11.0 (tested at $50^{\circ} \mathrm{C}$ ), with an optimum between $\mathrm{pH} 9.8$ and 10.3 (Fig. 9A). By the stringent definition of Krulwich and Guffanti (16), the isolates are facultative alkaliphiles. In contrast to aerobic alkaliphiles which lower or raise the $\mathrm{pH}$ in the medium to their optimal pH, as shown by Ueyama and Horikoshi (Fig. 2.3 , reference 11 ), none of the isolated anaerobic strains tested exhibited this phenomenon; because of the formation of acidic fermentation products, the $\mathrm{pH}$ became more acidic. The average change in $\mathrm{pH}$ ranged in the absence of glucose from 0.1 to $0.5 \mathrm{pH}$ unit and 0.4 to $1.0 \mathrm{pH}$ unit in the presence of $0.3 \%$ added glucose.

The marginal temperature data for growth in YTG medium ( $\mathrm{pH}$ 10.1) were as follows: $\mathrm{T}_{\max },>62^{\circ} \mathrm{C}$ and $<63.5^{\circ} \mathrm{C}$; $\mathrm{T}_{\text {opt }}$, 50 to $58^{\circ} \mathrm{C} ; \mathrm{T}_{\min },<32^{\circ} \mathrm{C}$ and $>30^{\circ} \mathrm{C}$ (incubation for up to 5 days; longer incubation times render the medium unsuitable). No significant differences were observed in the growth temperature optimum and range when the cells were grown in the presence and absence of glucose (Fig. 9B). With YT 

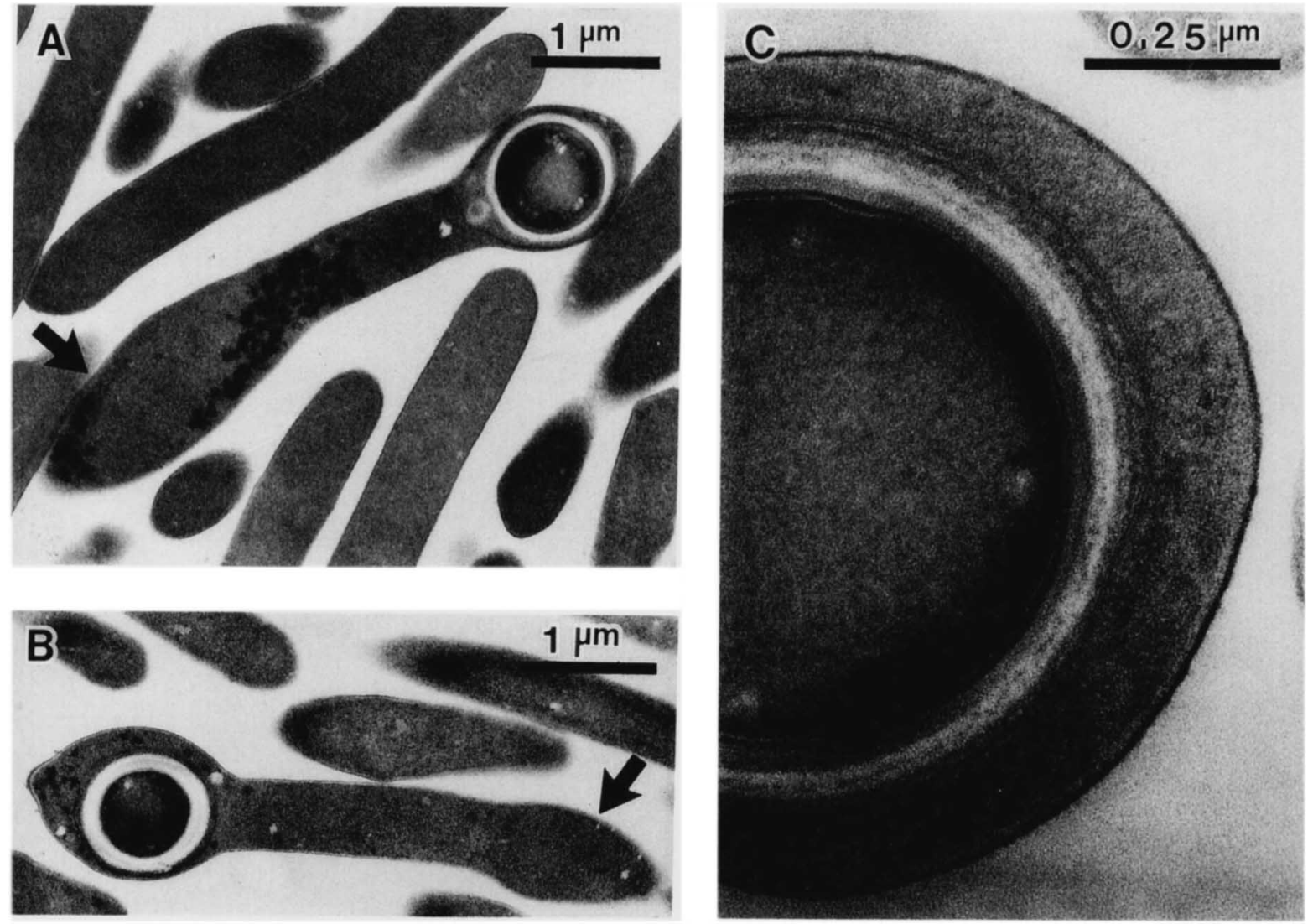

FIG. 6. Electron micrographs of ultrathin sections of sporulated cells (A and B) and endospore (C). Note the formation of the highly swollen cell end (A and B, arrow), which resembled the formation of an additional prespore-like structure on the distal end of the sporulated cell.
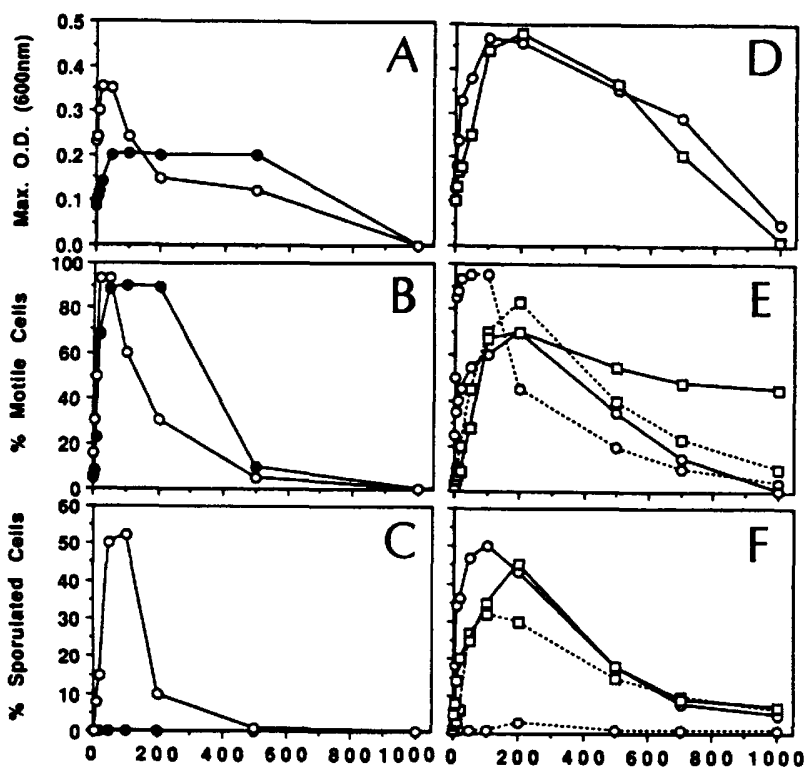

Sodium Chloride Added (mM) medium ( $0.5 \%$ yeast extract, $0.3 \%$ tryptone), the doubling time at the $\mathrm{pH}_{\mathrm{opt}}$ of 10.1 and $\mathrm{T}_{\mathrm{opt}}$ of $55^{\circ} \mathrm{C}$ was $16 \mathrm{~min}$ in the presence of $0.5 \%$ glucose and $22 \mathrm{~min}$ in the absence of glucose. This is the shortest doubling time observed for a strict anaerobic bacterium, regardless of the extreme environment. We speculate that this short doubling time could be one of the reasons that this alkali-thermophile can be found in relatively high numbers in mesophilic sewage sludge with $\mathrm{pH}$ values usually around neutral but, which, especially in pockets of the anaerobic sludge vessel, can undergo shifts in $\mathrm{pH}$ and temperature for short periods of time and thus render the environment temporarily favorable for these organisms to grow. However, the monitoring data we received from several of the sewage plants did not show any values above $38^{\circ} \mathrm{C}$ and $\mathrm{pH} 7.6$.

(ii) Effects of $\mathrm{Na}^{+}$and $\mathrm{K}^{+}$on growth. At $\mathrm{pH} 9.6$, the

FIG. 7. Effect of sodium ion concentration on growth (maximal $\left.\mathrm{OD}_{600}\right)(\mathrm{A}$ and $\mathrm{D})$, motility (B and $\mathrm{E}$ ), and sporulation (C and $\mathrm{F}$ ) in the absence $(A, B$, and $C)$ and presence $(D, E$, and $F)$ of added potassium ions. Closed symbols represent incubation at $\mathrm{pH} 7.5$, and all open symbols represent incubation at $\mathrm{pH} 9.6$. Concentrations of added $\mathrm{KCl}: \cdots \mathrm{O}^{\cdots} \cdot, 25 \mathrm{mM}, 2 \mathrm{~h} ; \cdots \square \cdots, 100 \mathrm{mM}, 2 \mathrm{~h} ;-0-, 25$ $\mathrm{mM}, 4$ and $10 \mathrm{~h} ;-\square-, 100 \mathrm{mM}, 4$ and $10 \mathrm{~h}$. The tests were done with cultures incubated at $50^{\circ} \mathrm{C}$ in YTG medium containing $0.25 \%$ yeast extract, $0.25 \%$ tryptone, $0.3 \%$ glucose, and in addition sodium and potassium salts at sodium and potassium ion concentrations of between 4 and 6 and 3 and $5 \mathrm{mM}$, respectively. Similar results were obtained in the absence of glucose (data not shown). 

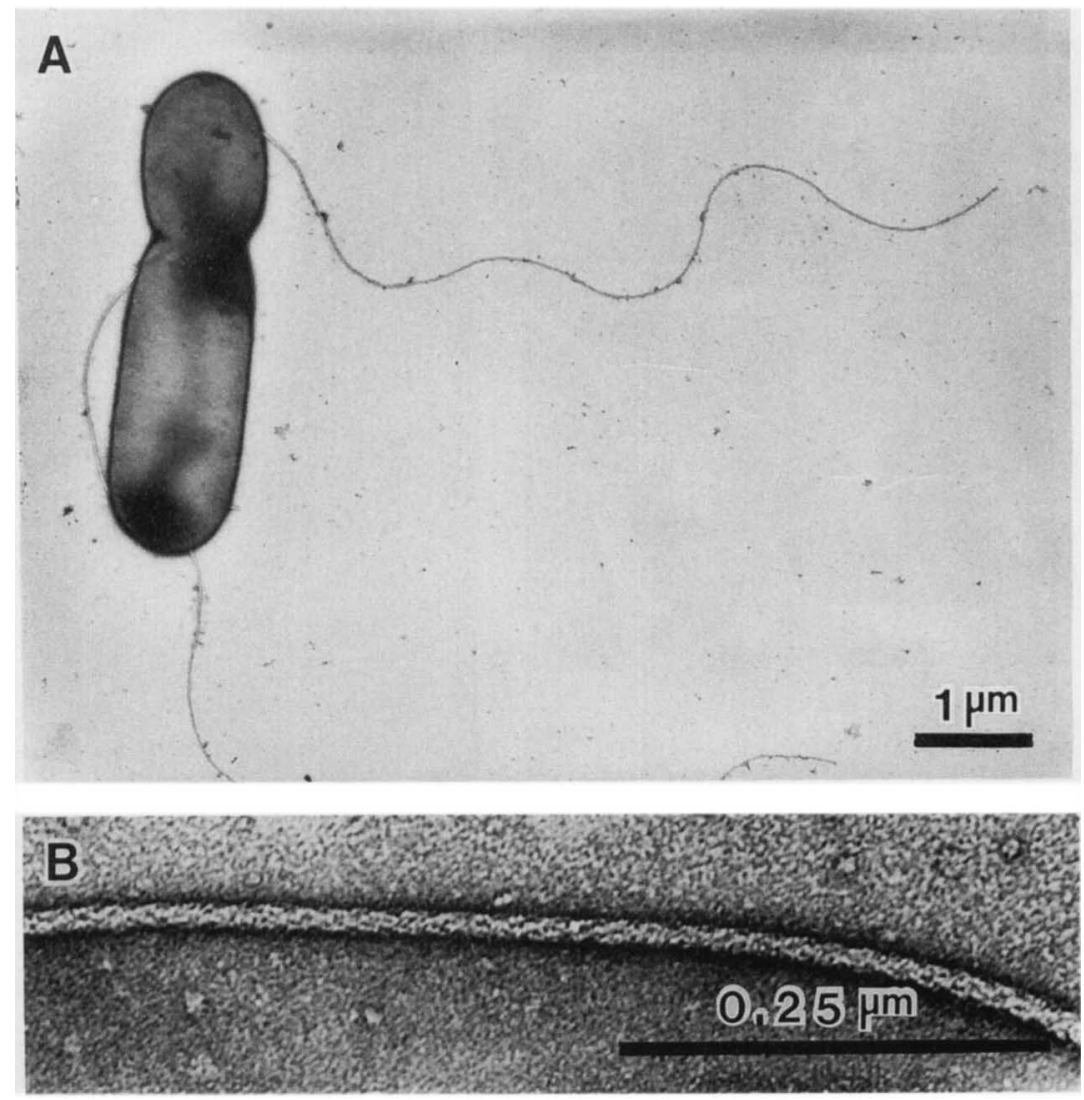

FIG. 8. Electron micrograph of a negatively stained cell with two flagella (A) and high magnification of a segment of a flagellum exhibiting the helical arrangement of the flagellin subunits (see text for further explanation) (B).

optimal sodium concentration for growth (maximal $\mathrm{OD}_{600}$ ) was between 50 and $100 \mathrm{mM}$, while at $\mathrm{pH} 7.5$ the range was extended to from 50 to $500 \mathrm{mM}$ (Fig. 7). The addition of 25 or $100 \mathrm{mM} \mathrm{KCl}$ increased the stimulation by $\mathrm{NaCl}$ and shifted the inhibitory effect of sodium ions to higher concentrations; e.g., in the presence of added potassium ion, the optimum concentration for growth was between 150 and 300 $\mathrm{mM} \mathrm{NaCl}$ instead of 50 to $100 \mathrm{mM} \mathrm{NaCl}$ without added potassium. At both alkaline and neutral $\mathrm{pH}$ values and in the presence and absence of added potassium ions, $1 \mathrm{M} \mathrm{NaCl}$ inhibited growth completely. Potassium had less of a stimulatory effect on growth than on motility and sporulation. In the presence of 25 and $100 \mathrm{mM}$ added $\mathrm{KCl}$, the optimum and inhibitory concentrations of added $\mathrm{NaCl}$ were shifted to higher concentrations (Fig. 7). Furthermore, in the presence of 25 to $100 \mathrm{mM}$ potassium, the extent of the sodium-induced effect was dependent on the culture age; e.g., at the early exponential growth phase $(2 \mathrm{~h})$ a higher percentage of cells were motile compared with the percentages in the late exponential growth phase and the transition phase (4 and 10 $h$, respectively). Furthermore, at the early exponential growth phase the optimal $\mathrm{NaCl}$ concentration was around 50 to $100 \mathrm{mM} \mathrm{NaCl}$. Similar data were obtained in the absence of glucose (data not shown).
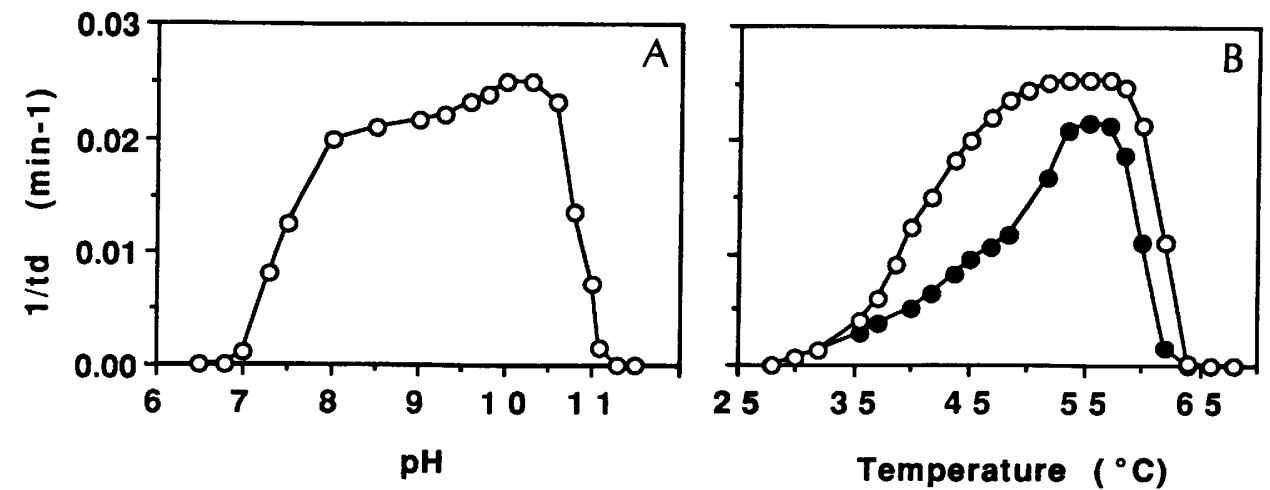

FIG. 9. Effects of $\mathrm{pH}(\mathrm{A})$ and temperature (B) on the growth rate of $C$. paradoxum JW-YL-7. The pH profile was obtained with YTP medium at $50^{\circ} \mathrm{C}$, and the temperature profile was obtained with YT $(\bullet)$ and YTG $(O)$ media at pH 10.1 . 
TABLE 3. Fermentation product analysis ${ }^{a}$

\begin{tabular}{|c|c|c|c|c|c|c|c|c|c|c|}
\hline \multirow{2}{*}{$\mathrm{pH}^{b}$} & \multirow{2}{*}{$\begin{array}{l}\text { Glucose } \\
\text { added }\end{array}$} & \multirow{2}{*}{$\begin{array}{c}\text { Glucose } \\
\text { used } \\
(\mu \mathrm{mol} / \mathrm{ml})\end{array}$} & \multicolumn{6}{|c|}{ Amt $(\mu \mathrm{mol} / \mathrm{ml})$ of product } & \multirow{2}{*}{ Unidentified $^{c}$} & \multirow{2}{*}{$\begin{array}{c}\text { Biomass } \\
\left(\mathrm{mg}[\mathrm{dry} \mathrm{wt}] \mathrm{ml}^{-1}\right)\end{array}$} \\
\hline & & & Acetate & $\mathrm{CO}_{2}$ & $\mathrm{H}_{2}$ & Isovalerate & Succinate & Butyrate & & \\
\hline \multirow[t]{2}{*}{10.5} & $0 \%$ & 0 & 3.3 & 4.3 & 2.3 & Trace & Trace & Trace & + & 0.26 \\
\hline & $0.3 \%$ & 6.2 & 10.5 & 5.6 & 4.8 & 0.8 & 0.7 & Trace & + & 0.5 \\
\hline \multirow[t]{2}{*}{7.5} & $0 \%$ & 0 & 2.1 & 6.7 & 2.5 & 1.5 & Trace & Trace & + & 0.2 \\
\hline & $0.3 \%$ & 3.2 & 2.8 & 8.1 & 2.3 & 0.7 & Trace & Trace & + & 0.26 \\
\hline
\end{tabular}

${ }^{a}$ Cultures were grown at $50^{\circ} \mathrm{C}$ for $7 \mathrm{~h}$ in YT (0.3\% yeast extract, $0.5 \%$ tryptone) and YTG (YT + 0.3\% glucose) at both pH 10.5 and 7.5 . A culture in an early exponential growth phase was used for a $5 \%$ (vol/vol) inoculum. Trace $=<0.5 \mu \mathrm{mol} / \mathrm{ml}$.

${ }^{b}$ Final pHs of the cultures were $10.4,10.0,7.0$, and 6.8 , respectively.

${ }^{c}$ Response peak in the gas chromatogram with a retention time of 14.84 min and a peak area of 5,000 or above.

The aeration pool samples and the anaerobic digestor samples from the Athens Sewage Plant had similar sodium concentrations ( 3 to $3.5 \mathrm{mM}$ ) but differed slightly in the potassium concentrations $(0.5$ versus $1.2 \mathrm{mM})$. These data suggest that $C$. paradoxum and alike strains live in the sewage sludge at suboptimal $\mathrm{Na}^{+}$and $\mathrm{K}^{+}$concentrations.

(iii) Substrates and fermentation products. No growth was observed under aerobic conditions, i.e., when aerobically prepared YTG, YTP, and nutrient broth (Difco) media, either liquid or solidified with $2 \%$ agar and with a $\mathrm{pH}$ of 10.1 , were used. The organism requires prereduced (i.e., resazurin-colorless) medium containing either yeast extract or tryptone, which cannot be replaced by peptone. The addition of 0.1 to $0.5 \%$ (wt/vol) peptone to media containing $0.3 \%$ (wt/vol) yeast extract or tryptone had no beneficial effect on growth. Substrates which were utilized in the presence of $0.1 \%$ (wt/vol) yeast extract included glucose, fructose, sucrose, maltose, and pyruvate. In addition, some strains were able to use lactose (JW-YL-4 and JW-YL-7 ${ }^{\mathrm{T}}$ ) and cellobiose and xylitol (JW-YL-2 and JW-YL- ${ }^{\mathbf{T}}$ ). The substrates not utilized were galactose, xylose, ribose, L- $(+)$-arabinose, mannose, mannitol, rhamnose, raffinose, salicin, sorbitol, malonate, glycerol, lactate, formate, pectin, starch, cellulose, ethanol, methanol, $\mathrm{H}_{2}-\mathrm{CO}_{2}$, and Casamino Acids. Moreover, the addition of $0.5 \%$ (wt/vol) D-mannose, methanol, and ethanol inhibited growth, compared with growth in unamended yeast extract-containing base medium. With or without glucose, at pH 7.5 and 10.5 , acetate, $\mathrm{CO}_{2}$, and $\mathrm{H}_{2}$ were the major products; however, one product could not be identified (Table 3).

Biochemical properties. (i) Dissimilatory sulfate reduction. No dissimilatory sulfate reduction was detected, thus excluding the organism from the sporeforming, dissimilatory sulfate-reducing genus Desulfotomaculum.

(ii) Fatty acid analysis. PLFAME (ester-linked phospholipid fatty acid methyl ester) profiles were determined (Table 4). Under alkaline growth conditions ( $\mathrm{pH} 10.1$ to 10.5 ), the patterns of PLFAME profiles of strains JW-YL-7 ${ }^{\mathrm{T}}$, JWYL-8, and JW/YL-L15-1 were similar but were different from the one obtained for an asporogenous strain, JW/YL23-2 ("C. thermophilum"; unpublished data), isolated from sewage sludge from the Atlanta Sewage Plant. However, when JW-YL-7 ${ }^{\mathrm{T}}$ was grown at $\mathrm{pH} 7.4$ to 7.6 , at which it does not form spores, its PLFAME pattern was similar to that of the Atlanta strain. However, further experiments, isolation of further strains, and data for other thermophiles and alkaliphiles are required before further conclusions can be drawn.

(iii) An-Ident tests. In An-Ident tests (API Analytab Products, Plainview, N.Y.), strong positive results were obtained for the following reactions: $\alpha$-glucosidase, indoxylacetate hydrolysis, arginine aminopeptidase, and arginine utilization. Weak positive reactions were found for indole production and catalase production. The other reactions $(N$-acetylglucosaminidase, L-arabinosidase, $\beta$-glucosidase, $\alpha$-fucosidase, $\alpha$-galactosidase, $\beta$-galactosidase, leucineaminopeptidase, proline aminopeptidase, pyroglutamic acid arylamidase, tyrosine aminopeptidase, alanine aminopeptidase, histidine aminopeptidase, phenylalanine aminopeptidase, and glycine aminopeptidase) were negative. The same results were obtained for incubations at either $\mathrm{pH} 8.5$ or 10.5 and at 37 or $50^{\circ} \mathrm{C}$.

(iv) Sensitivity to antibiotics. Strain JW-YL-7 ${ }^{\mathrm{T}}$ was tested in YTG medium at both $\mathrm{pH} 7.4$ and 10.1. Growth was inhibited by $25 \mu \mathrm{g}$ of chloramphenicol, erythromycin, tetracycline, monesin, gramicidin $\mathrm{S}$, and lasalocid per $\mathrm{ml}$ and 50 $\mu \mathrm{g}$ of gentamicin per $\mathrm{ml}$. The inhibition spectrum is in agreement with that for strains belonging to the (eu)bacteria.

(v) $\mathbf{G}+\mathbf{C}$ content (mole percent). The guanine-plus-cytosine content of the genomic DNA was $30.0 \pm 0.1 \mathrm{~mol} \%$ for the six tested strains, JW-YL-1, $-2,-4,-7^{\mathrm{T}},-8$, and -12 , as determined by complete $P 1$ nuclease and alkaline phosphatase digestion and HPLC analysis of the nucleosides $(22,32)$.

Type strain. Strain JW-YL-7, isolated from the sewage plant in Athens, Ga., is designated as the type strain of Clostridium paradoxum and is deposited with the German Culture Collection (DSM 7308). The G+C content of the

TABLE 4. Phospholipid fatty acid pattern (PLFAME analysis)

\begin{tabular}{lrrrr}
\hline & \multicolumn{4}{c}{$\%$} \\
\cline { 2 - 4 } \multicolumn{1}{c}{ PLFAME } & \multicolumn{2}{c}{ JW-YL-7 } & $\begin{array}{c}\text { JW-YL-8 } \\
\text { (pH 10.5) }\end{array}$ & $\begin{array}{c}\text { JW/YL-L15 } \\
\text { (pH 10.5) }\end{array}$ \\
\cline { 2 - 5 } & $\mathrm{pH}$ 7.5 & $\mathrm{pH} \mathrm{10.5}$ & & \\
\hline i13:0 & 4.42 & 0.81 & 0.91 & 1.03 \\
a13:0 & 0.70 & 0.20 & 0.22 & 0.24 \\
13:0 & 0.11 & 0.05 & 0.05 & 0.05 \\
i14:0 & 0.56 & 0.22 & 0.20 & 0.21 \\
14:0 & 5.96 & 2.07 & 2.77 & 2.44 \\
i15:0 & 65.04 & 60.63 & 60.85 & 64.98 \\
a15:0 & 7.24 & 7.77 & 7.92 & 7.84 \\
15:0 & 1.21 & 1.30 & 1.75 & 1.44 \\
i16:0 & 0.99 & 1.23 & 1.23 & 1.05 \\
16:1w7c & 0.19 & 0.10 & 0.12 & 0.09 \\
16:0 & 6.08 & 7.23 & 8.21 & 5.92 \\
i17:0 & 4.27 & 12.79 & 11.02 & 10.67 \\
a17:0 & 0.79 & 3.05 & 2.80 & 2.29 \\
17:0 & 0.13 & 0.26 & 0.23 & 0.17 \\
18:2w6 & 0.06 & 0.05 & 0.04 & 0.08 \\
i18:0 & 0.44 & 0.30 & 0.29 & 0.27 \\
18:1w7c & 0.27 & 0.17 & 0.14 & 0.14 \\
18:1w7t & 0.12 & 0.14 & 0.18 & 0.06 \\
18:0 & 1.42 & 1.64 & 1.05 & 1.01 \\
Total pmol/mg & 49,263 & 68,255 & 66,440 & 63,747 \\
\hline
\end{tabular}


type strain is $30 \mathrm{~mol} \%$. The properties are as described above for the species.

\section{ACKNOWLEDGMENTS}

We are indebted to W. B. Whitman for help with the $\mathrm{G}+\mathrm{C}$ content determination, C. R. Woese for the phylogenetic tree for $C$. paradoxum and related clostridia, M. Farmer for help with electron microscopy, D. C. White and D. Ringelberg for the fatty acid methyl ester analysis, and Suzanne DeBlois for helpful discussions. We also thank the following persons for providing sewage samples from various locations: D. R. Boone, Beaverton, Oreg.; J. M. Suflita, Norman, Okla.; W. Cooper, Miami, Fla.; D. Dalton, Gulf Breeze, Fla.; and M. Hernandez, San Francisco, Calif.

This work was supported by an industrial grant from NOVO Nordisk, Inc., Copenhagen, Denmark, and in part by a grant from the Department of Energy (DE-FG 09-86 ER-13614).

\section{REFERENCES}

1. Aragno, M., A. Walther-Mauruschat, F. Mayer, and H. G. Schlegel. 1977. Micromorphology of Gram-negative hydrogen bacteria. I. Cell morphology and flagellation. Arch. Microbiol. 114:93-100.

2. Ausubel, F. M. et al. 1989. Current protocols in molecular biology, p. 2.4.1-2.4.5. Wiley Interscience, New York.

3. Beuscher, N., F. Mayer, and G. Gottschalk. 1974. Citrate lyase from Rhodopseudomonas gelatinosa: purification, electron microscopy and subunit structure. Arch. Microbiol. 100:307-328.

4. Biggin, M. D., T. J. Gibson, and G. F. Hing. 1983. Buffer gradient gels and ${ }^{35} \mathrm{~S}$ label as an aid to rapid DNA sequence determination. Proc. Natl. Acad. Sci. USA 80:3963-3965.

5. Blotevogel, K., U. Fischer, M. Mocha, and S. Jannsen. 1985. Methanobacterium thermoalcaliphilum spec. nov., a new moderately alkaliphilic and thermophilic autotrophic methanogen. Arch. Microbiol. 142:211-217.

6. Boone, D. R., S. Worakit, I. M. Mathrani, and R. A. Mah. 1986. Alkaliphilic methanogens from high-pH lake sediments. Sysm. Appl. Microbiol. 7:230-234.

7. We Soete, G. 1983. A least square algorithm for fitting additive trees to proximity data. Psychometrika 48:621-626.

8. Frasca, J. M., and V. R. Parks. 1965. A routine technique for double-staining ultrathin sections using uranyl and lead salts. J. Cell Biol. 25:157-161.

9. Freier, D., C. P. Mothershed, and J. Wiegel. 1988. Characterization of Clostridium thermocellum JW-2r Appl. Environ. Microbiol. 54:204-211.

10. Grant, W. D., W. E. Mwatha, and B. E. J res. 15900. Alkaliphiles: ecology, diversity and applications. I EMS Microbiol. Rev. 75:255-270.

11. Horikoshi, K. 1990. Microorganisms in alkaline environments. Kodansha, Tokyo.

12. Jukes, T. H., and C. R. Cantor. 1969. Evolution of protein molecules, p. 21-132. In H. N. Munro (ed.), Mammalian protein metabolism. Academic Press, New York.

13. Kellenberger, E., A. Ryt $\mathbf{r}$, and J. Sechaud. 1958. Electron microscope study of DNA-containing plasma. II. Vegetative and mature phage DNA as compared with normal bacterial nucleosides in different physiological states. J. Biophys. Biochem. Cytol. 4:671-678.

14. Khraptsova, G. I., I. A. Tsaplina, L. M. Seregina, and L. G. Loginova. 1984. Thermophilic bacteria of the hot springs of Buryatia. Mikrobiologiya 53:137-141.

15. Kroll, R. G. 1990. Alkalophiles, p. 55-92. In C. Edwards (ed.), Microbiology of extreme environments. McGraw-Hill, New York.

16. Krulwich, T. A., and A. A. Guffanti. 1989. Alkalophilic bacteria. Annu. Rev. Microbiol. 43:435-463.

17. Lane, D. J., B. Pace, G. J. Olsen, and D. A. Stahl. 1985. Rapid determination of 16 S ribosomal RNA sequences for phylogenetic analyses. Proc. Natl. Acad. Sci. USA 82:6955-6959.

18. Liu, Y., D. R. Boone, and C. Choy. 1990. Methanohalophilus oregonense sp. nov., a methylotrophic methanogen from an alkaline, saline aquifer. Int. J. Syst. Bacteriol. 40:111-116.

19. Ljungdahl, L. G., and J. Wiegel. 1987. Anaerobic fermentations, p. 84-96. In A. L. Demain and N. A. Solomon (ed.), Manual of industrial microbiology. American Society for Microbiology, Washington, D.C.

20. Marmur, J. 1961. A procedure for the isolation of deoxyribonucleic acid from microorganisms. J. Mol. Biol. 3:208-218.

21. Mathrani, I. M., D. R. Boone, R. A. Mah, G. E. Fox, and P. P. Lau. 1988. Methanohalophilus zhilinae sp. nov., an alkaliphilic, halophilic, methylotrophic methanogen. Int. J. Syst. Bacteriol. 38:139-142.

22. Mesbah, M., U. Premachandran, and W. B. Whitman. 1989. Precise measurement of the $\mathrm{G}+\mathrm{C}$ content of deoxyribonucleic acid by high-performance liquid chromatography. Int. J. Syst. Bacteriol. 39:159-167.

23. Niimura, Y., E. Koh, F. Yanagida, K.-I. Suzuki, K. Komagata, and M. Kozaki. 1990. Amphibacillus xylanus gen. nov., sp. nov., a facultatively anaerobic sporeforming xylan-digesting bacterium which lacks cytochrome, quinone, and catalase. Int. J. Syst. Bacteriol. 40:297-301.

24. Olsen, G. J., R. Overbeek, N. Larsen, T. L. Marsh, M. J. McCaughey, M. A. Maciukenas, W. M. Kuan, T. J. Macke, and C. R. Woese. 1992. The ribosomal database project. Nucleic Acids Res. 20(Suppl.):2199-2200.

25. Sanger, F., S. Nicklen, and A. R. Coulson. 1977. DNA sequencing with chain-terminating inhibitors. Proc. Natl. Acad. Sci. USA 74:5463-5467.

26. Sharp, R. J., and M. J. Munster. 1986. Biotechnological implications for microorganisms from extreme environments, p. 215-295. In R. A. Herbert and G. A. Codd (ed.), Microbes in extreme environments. Academic Press, London.

27. Shiba, H., H. Yamamoto, and K. Horikoshi. 1989. Isolation of strictly anaerobic halophiles from the aerobic surface sediments of hypersaline environments in California and Nevada. FEMS Microbiol. Lett. 57:191-196.

28. Souza, K. A., P. H. Deal, H. M. Mack, and C. E. Turnbill. 1974. Growth and reproduction of microorganisms under extremely alkaline conditions. Appl. Microbiol. 28:1066-1068.

29. Spurr, A. R. 1969. A low-viscosity epoxy resin embedding medium for electron microscopy. J. Ultrastruct. Res. 26:31-43.

30. Valentine, R. C., B. M. Shapiro, and E. R. Stadtman. 1968. Regulation of glutamine synthetase. XII. Electron microscopy of the enzyme from $E$. coli. Biochemistry 7:2143-2152.

31. Weisburg, W. G., J. G. Tully, D. L. Rose, J. P. Petzel, H. Oyaizu, D. Yang, L. Mandelco, J. Sechrest, T. G. Lawrence, J. van Etten, J. Manilofi, and C. R. Woese. 1989. A phylogenetic analysis of the Mycoplasmas: Basis for their classification. $\mathrm{J}$. Bacteriol. 171:6455-6467.

32. Whitman, W. B., S. Sohn, D. S. Caras, and U. Premachandran. 1986. Isolation and characterization of 22 mesophilic methanococci. Syst. Appl. Microbiol. 7:235-240.

33. Wiegel, J. 1981. Distinction between the Gram reaction and the Gram type of bacteria. Int. J. Syst. Bacteriol. 31:88.

34. Wiegel, J., L. G. Ljungdahl, and J. R. Rawson. 1979. Isolation from soil and properties of the extreme thermophile Clostridium thermohydrosulfuricum. J. Bacteriol. 139:800-810.

35. Wiegel, J., and L. Quandt. 1982. Determination of the Gram type using the reaction between polymyxin B and lipopolysaccharides of the outer cell wall of whole bacteria. J. Gen. Microbiol. 128:2261-2270.

36. Woese, C. R., R. Gutell, R. Gupta, and H. F. Noller. 1983. Detailed analysis of the higher-order structure of 16S-like ribosomal ribonucleic acids. Microbiol. Rev. 47:621-669.

37. Woese, C. R., M. Sogin, D. A. Stahl, B. J. Lewis, and L. Bonen. 1976. A comparison of the $16 \mathrm{~S}$ ribosomal RNAs from mesophilic and thermophilic bacilli. J. Mol. Evol. 7:197-213.

38. Worakit, S., D. R. Boone, R. A. Mah, M. Abdel-Samie, and M. M. El-Halwagi. 1986. Methanobacterium alcaliphilum sp. nov., an $\mathrm{H}_{2}$-utilizing methanogen that grows at high $\mathrm{pH}$ values. Int. J. Syst. Bacteriol. 36:380-382. 